\title{
Analysis of the Practice of Monitoring and Evaluation in Development Projects in Mali
}

\author{
Salia TRAORE ${ }^{1}$ KONE Abdrahamane ${ }^{2} \quad$ Aly YOROTE $^{2} \quad$ Lin WANG $^{3}$ \\ 1.Maître de Conférences, Faculté des Sciences Economiques et de Gestion de l'Université des Sciences Sociales \\ et de Gestion de Bamako \\ 2.Maître Assistant, Faculté des Sciences Economiques et de Gestion de l’Université des Sciences Sociales et de \\ Gestion de Bamako \\ 3.Jilin jianzhu University China
}

\section{Acknowledgement}

The researchers present their thanks and appreciation to all the structures and people who contributed to the production of this article.

\begin{abstract}
The objective of this work is to analyze and highlight monitoring and evaluation as practiced in development projects in Mali by managers. The methodology is based on a documentary review of various works dealing with issues of monitoring and evaluation, management of development projects, documents of development projects as well as rich and cordial interviews allowed us to build our analysis model. The implementation of monitoring and evaluation in development projects was measured according to a number of variables that related to the understanding of its usefulness, as well as the implementation mechanisms and the identification of methods and tools. The results of our research did not allow us to confirm or refute the hypotheses that had been put forward to try to explain the problem of the practice of monitoring and evaluation in Mali. However, the analysis of the results shows that knowledge of monitoring and evaluation is approximate, the practice is contrary to theoretical prescriptions and the tools and methods are little known and poorly used.
\end{abstract}

Keywords: Monitoring, Evaluation, Project et program.

DOI: $10.7176 / \mathrm{EJBM} / 13-22-02$

Publication date: November $30^{\text {th }} 2021$

\section{INTRODUCTION}

In recent years, there has been a growing interest from donors and agencies in monitoring and evaluation for better achievement of the objectives of the projects they finance and execute. Nowadays, monitoring and evaluation are at the heart of the management of development projects and programs in Africa in general and in Mali in particular. "Monitoring and evaluation" is seen more as a requirement of development partners than as an administrative tool.

A monitoring and evaluation system is indeed an important management tool that allows governments, development programs, and projects to improve the way they manage and the way they achieve results. Since the monitoring and evaluation system is, therefore, an effective means of measuring progress, it can provide feedback on the performance of projects and programs.

To provide an initial answer to our questioning, we opted for a mixed approach between qualitative research and quantitative research. Indeed, research work on the subject in Mali is almost non-existent, to provide an initial answer to our questioning, we opted for a mixed approach between qualitative research and quantitative research. Indeed, research work on the subject in Mali is almost non-existent, and to better understand our subject, we relied on the available literature that dealt with the question. After drawing up an interview guide, this approach enabled us to conduct in-depth semi-structured interviews with certain monitoring and evaluation practitioners working in development projects. The elements identified during the qualitative phase allowed us to move on to the quantitative phase with the development of a questionnaire and its administration to a sample of fifty (50) people, all practitioners of monitoring and evaluation in the development of the project of Mali..

However, the effectiveness of all these responses will lie in the understanding and use of monitoring and evaluation tools in development projects in Mali. This prompts us to reflect and pose the following problem: Why are the monitoring and evaluation implemented in development projects in Mali not yielding the expected results?

To provide elements to this issue, this paper will be organized into two parts: The first will be devoted to the contextual and methodological framework and in the second part we will present the practice of monitoring and evaluation in development projects in Mali.

\section{Literature review}

Monitoring and evaluation is an information system and a decision-making tool, made up of actors, data whose production, organization, and circulation are governed by procedures, and which is part of the process management 
of projects and programs. Monitoring and evaluation is a recent discipline that is gaining more and more important in the management of projects and programs (Neu, 2001).

According to the World Bank, the monitoring and evaluation of development activities give governments, development managers, and civil society the best means to learn from experience, improve service delivery, plan and allocate resources, and report to key stakeholders on results achieved. In addition, this World Bank study shows that monitoring and evaluation activities are attracting more and more interest and topicality because the development community places a premium on achieving results. It is this growing interest in monitoring and evaluation that led African countries to adopt in 2003 the support program for monitoring Poverty Reduction Strategy Papers and Millennium Development Indicators.

It should be noted that as of February 3, 2020, the active portfolio of the World Bank in Mali comprises thirtyone (31) operations financing twenty-seven (27) projects, including nineteen (19) of a national nature and eight (08) regional, for a total committed amount of US \$ 1,684.55 million, or approximately CFAF 999.81 billion. The total financial commitment to national projects is US $\$ 1,354.05$ million $(80.38 \%)$ and that to regional projects is US \$ 330.50 million (19.62\%).

This progressive quest for monitoring and evaluation of donor investments has also led to the birth of ResultsBased Management (RBM), a monitoring-evaluation approach that places more emphasis on obtaining results by projects, programs, and public policies.

It is obvious that financial partners understand the destination of the funds they allocate, and that they are used wisely. But monitoring and evaluation should firstly allow an organization or a project to know for themselves whether they are in agreement with the objectives, whether they have an impact, and ultimately allow them to bring together all this information more efficiently.

The problems observed in the monitoring and evaluation of projects in Africa was also raised by the International Development Association (IDA). In fact, in November 2007, IDA conducted a questionnaire survey of all of its projects, field visits, and a diagnosis of the monitoring and evaluation training offer. The diagnosis noted several problems encountered by development programs and projects in their monitoring and evaluation system.

In Mali, after a few years of monitoring and evaluation practice in development projects, the same observation emerges. There is a lack of understanding between the different partners. The beneficiaries do not recognize themselves in the conclusions of the studies carried out, the evaluators have the impression of preaching in a vacuum, the project managers consider monitoring and evaluation as a tool of repression and have the impression of being the main tar In Mali, after a few years of monitoring and evaluation practice in development projects, the same observation emerges. There is a lack of understanding between the different partners. The beneficiaries do not recognize themselves in the conclusions of the studies carried out, the evaluators have the impression of preaching in a vacuum, the project managers consider monitoring and evaluation as a tool of repression and have the impression of being the main target, while donors make their decisions without taking into account the results obtained following the implementation of monitoring and evaluation.

Taking into account monitoring and evaluation in understanding these phenomena can lead to a good orientation of development aid policies as well as the design and implementation of adapted projects likely to provide a response to previously expressed needs get, while donors make their decisions without taking into account the results obtained following the implementation of monitoring and evaluation.

Taking into account monitoring and evaluation in understanding these phenomena can lead to a good orientation of development aid policies as well as the design and implementation of adapted projects likely to provide a response to previously expressed needs.

\section{III.PROBLEM AND METHODOLOGY}

The issue of monitoring and evaluation in development projects no longer needs to be demonstrated but, of all the tools available to the project manager to carry out his mission of change and transformation through sound management, monitoring and evaluation is the one that generates the most passions. Indeed, as it gains in intensity in its implementation, it begins to disappoint.

\subsection{PROBLEM}

Mali, where the practice of monitoring and evaluation is recent, is currently at a crossroads because of the choices it must make for its economic and social development through good governance and the fight against poverty. In fact, three elements seem to us to constitute opportunities for the practice of monitoring and evaluation in project management in Mali.

The first element is in favor of the usefulness of monitoring and evaluation insofar as it makes it possible to increase the information available on an action; it also provides information on the issues, means and results.

The second element is the current situation in Mali, characterized by the security crisis, bad governance and corruption which manifest themselves in the management of development projects through serious shortcomings 
observed in the use of the resources made available in these projects; thus compromising the achievement of results.

Finally, the third element is the policy of rigor and moralization in the management of public affairs initiated by the Malian authorities. International donors, who are increasingly looking at the justification of the use of financial resources and the achievement of results, fight against poverty and sustainability of effects through the learning process.

It is obvious that financial partners understand the destination of the funds they allocate, and that they are used wisely. But monitoring and evaluation should firstly allow an organization or a project to know for themselves whether they are in agreement with the objectives, whether they have an impact, and ultimately allow them to bring together all these information more efficiently. Thus, monitoring and evaluation consists of collecting data on the progress of a Project/Program, then analyzing them regularly in order to draw conclusions in terms of project management. From this observation, monitoring-evaluation becomes more necessary than ever for the successful achievement of the desired results during the planning of Projects/Programs. However, the monitoring and evaluation function nowadays seems to be a simple formality to be integrated into the design and implementation of daily development actions. In fact, in order for a Projects/Programs to achieve the expected ultimate results, it should be equipped with a high-performance monitoring and evaluation system which represents a warning tool and monitoring its proper conduct.

In a context characterized by the relative youth of the practice of monitoring and evaluation, the techniques and methods applied are still far from perfect. In the majority of development projects in Mali, the practice of monitoring and evaluation is still in its infancy, but it is already giving rise to conflicts between the various partners because they do not always agree on the results obtained at the end of the evaluations. It is the management of these projects with the objective of achieving developmental results and optimizing impact that is taking a hit. It is necessary to clearly define how monitoring and evaluation are put into practice before considering the possible corrections that could be made, hence our central research question: Why is the monitoring and evaluation implemented in development projects in Mali not yielding the expected results?

To better understand the practice of monitoring and evaluation in development projects in Mali and to understand why the results are mixed, we have formulated three hypotheses which will allow us to provide the beginnings of answers to our questions. The analysis of the practice of monitoring and evaluation in development projects in Mali is based on a number of hypotheses that we will study. On the one hand, monitoring and evaluation must be able to provide up-to-date information, meeting the criteria of relevance, good quality and impact. On the other hand, based on the documents consulted and with regard to the practice which is made of them, the results obtained could be explained by the hypotheses below:

Hypothesis 1: The importance given to monitoring and evaluation in its implementation depends on the understanding of its usefulness in the development project.

Hypothesis 2: The use made of monitoring and evaluation reports by development project managers depends on understanding their usefulness.

Hypothesis 3: The use made of monitoring and evaluation reports by development project managers does not depend on how often they are carried out.

\subsection{Research Methodology}

The resolution of any management problem, whether in fundamental or applied research, requires a scientific and therefore rigorous approach, which will guarantee the professional character of the study and therefore of the final result. This observation presupposes that faced with a problem, the project manager would be able to establish a rigorous approach to achieve relevant results that will help to clarify its resolution. To do this, he must try to operationalize the variables to be handled, by adapting them to the situation. This adaptation is only possible thanks to a good knowledge of the subject to be treated. The project manager can only achieve this thanks to a documentary and exploratory research which will allow him to clearly define the problem to be treated.

Once this prerequisite has been established, the project manager must be able to develop a data collection and analysis plan based on the relationships identified and to set up the necessary processing techniques and statistical tools.

The description of the practice of monitoring and evaluation in Mali can only is possible if all the principles of this approach are integrated. 
IV.data analysis and interpretation

Table 1: Distribution of the sample according to the position held in the project and the sector of execution.

\begin{tabular}{|l|l|l|l|l|}
\hline Position in the project & \multicolumn{3}{|c|}{ Project sector } & Total \\
\cline { 2 - 4 } & Education & Health & Agriculture & \\
\hline Project manager & 7 & $\mathbf{8}$ & $\mathbf{1 0}$ & $\mathbf{2 5}$ \\
\hline Responsible for monitoring and evaluation in the project & $\mathbf{7}$ & $\mathbf{8}$ & $\mathbf{1 0}$ & $\mathbf{2 5}$ \\
\hline Total & $\mathbf{1 4}$ & $\mathbf{1 6}$ & $\mathbf{2 0}$ & $\mathbf{5 0}$ \\
\hline
\end{tabular}

Source: Data collected by us

The analytical techniques that were used in this study were based on association tests measured by the "chisquare" statistic.

The methodology thus described allowed us to highlight the practice of monitoring and evaluation in development projects in Mali. It also allowed us to verify the links between the variables identified, while integrating all the elements necessary to minimize the risk of bias.

4.1. Presentation and descriptive analysis of the results of the practice of monitoring and evaluation in development projects in Mali:

Descriptive analysis of results in monitoring concerns understanding the usefulness of monitoring and evaluation, as well as the implementation mechanism and identification of methods and tools.

411. Degree of understanding of usefulness of monitoring:

- Understanding the usefulness of monitoring

Respondents had three choices to make from the items identified to answer the question. As we can see, the first and the third statement obtained percentages greater than or equal to $26.1 \%$, thus demonstrating that the majority of respondents gave a definition of follow-up corresponding to these two statements. Indeed $60 \%$ of respondents chose the third statement, $26 \%$ the first statement while only $14 \%$ of respondents chose the second statement.

Table 2: Respondents' understanding of the usefulness of follow-up.

\begin{tabular}{|l|l|l|}
\hline Modalities & $\begin{array}{l}\text { Absolute } \\
\text { frequency }\end{array}$ & $\begin{array}{l}\text { Relative } \\
\text { frequency\% }\end{array}$ \\
\hline $\begin{array}{l}\text { Continuous process of collecting and analyzing data relating to performance } \\
\text { indicators which aims to compare the degree of success of interventions for } \\
\text { the development of partnerships or policy reforms against the expected results }\end{array}$ & 13 & 26 \\
\hline $\begin{array}{l}\text { Ongoing management function that primarily aims to provide administrators } \\
\text { and key stakeholders with regular feedback and early indications on the } \\
\text { progress (or lack thereof) of ongoing or completed projects }\end{array}$ & 07 & 14 \\
\hline $\begin{array}{l}\text { Collection of quantitative and qualitative information on pre-established } \\
\text { indicators to measure the progress made in the implementation of programs } \\
\text { and their impact. It also contributes to decision-making allowing the efficient } \\
\text { execution of projects. }\end{array}$ & 30 & 60 \\
\hline Total & $\mathbf{5 0}$ & $\mathbf{1 0 0}$ \\
\hline
\end{tabular}

Source: Data collected by us

4.1.2 Implementation mechanism and identification of tools:

The follow-up in the respondent's intervention projects is implemented by several techniques. In fact, for $38 \%$ of respondents, monitoring is implemented in their intervention projects by monitoring achievements and for $20 \%$ of respondents, by monitoring the quality of progress and achievements. On the other hand, for $16 \%$ of respondents, the implementation of monitoring is done by analyzing the dashboard, while for $14 \%$, it is done by monitoring progress. Finally, for $12 \%$ of respondents, monitoring is carried out by simply checking the reactions of beneficiaries.

Table 3: Implementation of monitoring in respondent intervention projects.

\begin{tabular}{|l|l|l|}
\hline Modalities & $\begin{array}{l}\text { Absolute } \\
\text { frequency }\end{array}$ & $\begin{array}{l}\text { Relative } \\
\text { frequency } \%\end{array}$ \\
\hline By monitoring the progress & 7 & 14 \\
\hline By controlling achievements & 19 & 38 \\
\hline By monitoring the reactions of beneficiaries & 6 & 12 \\
\hline By analyzing the dashboard & 8 & 16 \\
\hline By controlling the quality of the process and the achievements & 10 & 20 \\
\hline Total & $\mathbf{5 0}$ & $\mathbf{1 0 0}$ \\
\hline
\end{tabular}

Source: Data collected by us 


\subsection{Hypothesis tests:}

The objective of bivariate analysis is to investigate the relationships that may exist between the variables taken in pairs (Perrien et al, 1984). Within the framework of this study, we used the chi-square statistic to test the hypotheses after the creation of the contingency tables between the variables to be tested.

\subsection{Understanding the usefulness of monitoring and evaluation in a development project in Mali:} Hypothesis 1: Verification

We hypothesized to show the relationship between the importance given to monitoring and evaluation in its implementation and the understanding of its usefulness for the development project. This hypothesis was analyzed by cross-tabulation and tested by the chi-square statistic with a critical threshold of 0.05 (a confidence level of $95 \%)$.

Unfortunately, this hypothesis could not be verified for both monitoring and evaluation. Indeed for the followup, two cells had absolute frequencies lower than five. For evaluation, two cells also had absolute frequencies less than five.

Table 4: Understanding of the usefulness of monitoring * importance of monitoring and evaluation in development projects.

\begin{tabular}{|l|l|l|l|}
\hline \multirow{2}{*}{ Understanding the usefulness of monitoring } & $\begin{array}{l}\text { Importance of monitoring and } \\
\text { evaluation in development } \\
\text { projects }\end{array}$ & Total \\
\cline { 2 - 4 } & Very important & Important \\
\hline $\begin{array}{l}\text { Continuous process of collecting and analyzing data relating to } \\
\text { performance indicators that aims to compare the degree of success } \\
\text { of interventions for the development of partnerships or policy } \\
\text { reforms against the expected results }\end{array}$ & 11 & 2 & 13 \\
\hline $\begin{array}{l}\text { Ongoing management function that primarily aims to provide } \\
\text { administrators and key stakeholders with regular feedback and early } \\
\text { indications on the progress (or lack thereof) of ongoing or completed } \\
\text { projects }\end{array}$ & 7 & 0 & 7 \\
\hline $\begin{array}{l}\text { Collection of quantitative and qualitative information on pre- } \\
\text { established indicators to measure the progress made in the } \\
\text { implementation of programs and their impact. It also contributes to } \\
\text { decision-making allowing the efficient execution of projects. }\end{array}$ & & \\
\hline Total & & 5 \\
\hline
\end{tabular}

Source: Data collected by us

Table 5: Understanding of the usefulness of evaluation * importance of monitoring and evaluation in development projects.

\begin{tabular}{|l|l|l|l|}
\hline \multirow{2}{*}{ Understanding the usefulness of evaluation } & $\begin{array}{l}\text { Importance of monitoring and } \\
\text { evaluation in development projects }\end{array}$ & Total \\
\cline { 2 - 3 } & very important & Important & \\
\hline $\begin{array}{l}\text { Usually involves the collection and analysis of data related to } \\
\text { the process and results of a project }\end{array}$ & 8 & 4 & 12 \\
\hline $\begin{array}{l}\text { Operation limited in time which aims to systematically and } \\
\text { objectively assess the relevance, performance and success of } \\
\text { ongoing or completed development projects }\end{array}$ & 21 & 2 & 23 \\
\hline $\begin{array}{l}\text { Is undertaken selectively to answer specific questions that } \\
\text { will guide decision-makers / or project managers, and to } \\
\text { provide information that will determine whether the theories } \\
\text { and starting assumptions used in developing the project were } \\
\text { valid, resulting in or did not give results and why }\end{array}$ & & 0 & \\
\hline Total & & & 15 \\
\hline
\end{tabular}

\section{Source: Data collected by us}

Hypothesis 2: Verification

This hypothesis was put forward to show the relationship that could exist between understanding the value of monitoring and evaluation and the use made of monitoring and evaluation reports in project management. This hypothesis was analyzed by cross-tabulation and tested by the chi-square statistic with a critical threshold of 0.05 (ie a confidence level of $95 \%$ ).

Unfortunately, this hypothesis could not be verified. In fact, in the case of follow-up, five cells had absolute 
frequencies lower than five. The same operation carried out in the case of the evaluation where two cells had absolute frequencies less than five, led to the same results.

Table 6: Use of monitoring reports * understanding the usefulness of monitoring.

\begin{tabular}{|c|c|c|c|c|}
\hline \multirow[b]{2}{*}{$\begin{array}{l}\text { Understanding the usefulness of } \\
\text { monitoring }\end{array}$} & \multicolumn{3}{|c|}{$\begin{array}{l}\text { Use made of monitoring reports by development project } \\
\text { managers }\end{array}$} & \multirow[t]{2}{*}{ Total } \\
\hline & $\begin{array}{l}\text { Project } \\
\text { management tool } \\
\text { and means of } \\
\text { checking facts in } \\
\text { the field }\end{array}$ & $\begin{array}{l}\text { Ensure that } \\
\text { the project is } \\
\text { progressing } \\
\text { well towards } \\
\text { its objectives }\end{array}$ & $\begin{array}{l}\text { Make any necessary } \\
\text { corrective adjustments } \\
\text { during execution } \\
\text { without waiting for the } \\
\text { evaluation }\end{array}$ & \\
\hline $\begin{array}{l}\text { Continuous process of collecting } \\
\text { and analyzing data relating to } \\
\text { performance indicators that aims to } \\
\text { compare the degree of success of } \\
\text { interventions for the development } \\
\text { of partnerships or policy reforms } \\
\text { against the expected results }\end{array}$ & 6 & 4 & 3 & 13 \\
\hline $\begin{array}{l}\text { Ongoing management function that } \\
\text { primarily aims to provide } \\
\text { administrators and key stakeholders } \\
\text { with regular feedback and early } \\
\text { indications on the progress (or lack } \\
\text { thereof) of ongoing or completed } \\
\text { projects }\end{array}$ & 0 & 5 & 2 & 7 \\
\hline $\begin{array}{l}\text { Collection of quantitative and } \\
\text { qualitative information on pre- } \\
\text { established indicators to measure } \\
\text { the progress made in the } \\
\text { implementation of programs and } \\
\text { their impact. It also contributes to } \\
\text { decision-making allowing the } \\
\text { efficient execution of projects. }\end{array}$ & 3 & 4 & 23 & 30 \\
\hline Total & 9 & 13 & 28 & 50 \\
\hline
\end{tabular}

\section{Source: Data collected by us}

Table 7: Use of evaluation reports * understanding of the usefulness of the evaluation.

\begin{tabular}{|c|c|c|c|c|}
\hline \multirow[t]{2}{*}{ Understanding the usefulness of evaluation } & \multicolumn{3}{|c|}{$\begin{array}{l}\text { Use made of evaluation reports by development } \\
\text { project managers }\end{array}$} & \multirow[t]{2}{*}{ Total } \\
\hline & $\begin{array}{l}\text { Measure the } \\
\text { impact or } \\
\text { general long- } \\
\text { term results }\end{array}$ & $\begin{array}{l}\text { Determine the } \\
\text { overall } \\
\text { effectiveness } \\
\text { of the project }\end{array}$ & $\begin{array}{l}\text { Reorient the } \\
\text { phases of the } \\
\text { project according } \\
\text { to the resources }\end{array}$ & \\
\hline $\begin{array}{l}\text { Usually involves the collection and analysis of } \\
\text { data related to the process and results of a } \\
\text { project }\end{array}$ & 5 & 5 & 2 & 12 \\
\hline $\begin{array}{l}\text { Operation limited in time which aims to } \\
\text { systematically and objectively assess the } \\
\text { relevance, performance and success of } \\
\text { ongoing or completed development projects }\end{array}$ & 7 & 7 & 9 & 23 \\
\hline $\begin{array}{l}\text { Is undertaken selectively to answer specific } \\
\text { questions that will guide decision-makers / or } \\
\text { project managers, and to provide information } \\
\text { that will determine whether the theories and } \\
\text { starting assumptions used in developing the } \\
\text { project were valid, resulting in or did not give } \\
\text { results and why }\end{array}$ & 10 & 4 & 1 & 15 \\
\hline Total & 22 & 16 & 12 & $\mathbf{5 0}$ \\
\hline
\end{tabular}

Source: Data collected by us 


\section{Hypothesis 3: Verification}

This hypothesis was put forward to verify the relationship between the use made of monitoring and evaluation reports by development project managers and the frequency of implementation. It was analyzed by cross-tabulation and tested by chi-square statistics with a critical threshold of 0.05 (ie a confidence level of $95 \%$ ).

Unfortunately, this hypothesis could not be verified. Indeed for the follow-up, 11 cells had absolute frequencies less than five. The same operation carried out in the case of the evaluation showed that eight cells had absolute frequencies less than five.

Table 8: Use of monitoring reports * frequency of implementation.

\begin{tabular}{|l|l|l|l|l|l|l|}
\hline \hline Use made of monitoring reports & \multicolumn{2}{l|}{ Frequency of monitoring } & Total \\
\cline { 2 - 7 } & Daily & Weekly & Monthly & Quarterly & Annual & \\
\hline $\begin{array}{l}\text { Project management tool and means of } \\
\text { checking the facts on the ground, which make } \\
\text { it possible to ensure that the objectives are not } \\
\text { sacrificed, nor neglected or abandoned along } \\
\text { the way }\end{array}$ & & 4 & 1 & 0 & 0 & 10 \\
\hline $\begin{array}{l}\text { Ensure that the project is progressing well } \\
\text { towards its objectives }\end{array}$ & 2 & 4 & 2 & 2 & 2 & 12 \\
\hline $\begin{array}{l}\text { Make necessary adjustments and fixes during } \\
\text { execution without waiting for evaluation }\end{array}$ & 22 & 2 & 3 & 1 & 0 & 28 \\
\hline Total & $\mathbf{2 9}$ & $\mathbf{1 0}$ & $\mathbf{6}$ & $\mathbf{3}$ & $\mathbf{2}$ & $\mathbf{5 0}$ \\
\hline
\end{tabular}

Source: Data collected by us

Table 9: Use of evaluation reports * frequency of carrying out the evaluation.

\begin{tabular}{|l|l|l|l|l|l|}
\hline \hline \multirow{2}{*}{ Use of evaluation reports } & \multicolumn{2}{|l|}{ Frequency of assessment } & Total \\
\cline { 2 - 6 } & Very often & often & Occasionally & Never & \\
\hline $\begin{array}{l}\text { Measure the general and long-term impact or results } \\
\text { of a project }\end{array}$ & 15 & 3 & 6 & 0 & $\mathbf{2 4}$ \\
\hline Determine the overall effectiveness of the project & 16 & 0 & 0 & 0 & $\mathbf{1 6}$ \\
\hline $\begin{array}{l}\text { Reorient the phases of the project according to the } \\
\text { available resources }\end{array}$ & 9 & 1 & 0 & 0 & $\mathbf{1 0}$ \\
\hline Total & $\mathbf{4 0}$ & $\mathbf{4}$ & $\mathbf{6}$ & $\mathbf{0}$ & $\mathbf{5 0}$ \\
\hline
\end{tabular}

\subsection{Summary of the results:}

These results show that for the respondents, monitoring and evaluation is important. Even if they differ on the reasons, the fact remains that these reasons have one point in common which is based on the measurement and control of results.

When it comes to understanding the usefulness of evaluation, respondents have different views. Indeed an absolute majority could not be released about this statement. For monitoring, we note a clear superiority of respondents $((60 \%)$ who think that monitoring is a collection of quantitative and qualitative information on preestablished indicators to measure the progress made in the implementation of programs and their impact. also contributes to decision-making to effectively execute projects.

Regarding the use of monitoring reports, respondents are also divided, but we still see a majority of respondents $(56 \%)$ who think that the monitoring reports of a development project are used to make adjustments. fixes needed during execution without waiting for evaluation.

An analysis of the monitoring tools known by the respondents shows that $42 \%$ know the logical framework a priori, a qualitative and quantitative indicator, $26 \%$ the qualitative and quantitative indicators while $22 \%$ of the respondents know the logical framework a priori, a logical framework a posteriori qualitative indicator and quantitative indicator. Finally, $6 \%$ of respondents know the logical framework a priori, the logical framework a posteriori, the qualitative and quantitative indicators, and the scoreboard while the remaining $4 \%$ only know the logical framework a priori and the logical framework a posteriori. The majority of respondents, ie $96 \%$ use these tools in the projects in which they are involved, while only $4 \%$ of respondents certainly use them.

Respondents also have divergent positions regarding the stages of the assessment. The stages of the assessment vary from one development project to another. Indeed, for $52 \%$ of respondents, the stages of the evaluation include the development of TOR, the choice of methods, the development of tools, and the collection of data, while for $20 \%$ of the respondents, these stages include the definition indicators, preparation of the event, and identification of actors. On the other hand, for $12 \%$ of the respondents, the stages of the evaluation include the preparation of invitations and the descent into the field for $10 \%$ of the respondents, these stages consist of the preparation of documents and discussion with the stakeholders, while for the $6 \%$ these stages include planning - 
development of tools - discussion with stakeholders.

The difficulties encountered in the implementation of monitoring and evaluation of development projects in Mali is varied. Indeed, for $36 \%$ of the respondents, the absence of reliable statistics and the logical framework in the project, the poor definition of indicators are at the origin of the main difficulties encountered in the implementation of development projects in Mali.

\section{Conclusion}

The results obtained in this study allowed us to highlight the practice of monitoring and evaluation in development projects in Mali, the methods and tools used as well as the frequency of implementation and the people involved. The three hypotheses put forward to explain and understand why monitoring and evaluation as practiced in the Malian context does not give the expected results could not be verified.

These results find their explanations within methodological and conceptual limits. The limits related to the methodology relate to the measuring instrument used, the data processing carried out, the size and the choice of the sample.

Regarding the limits of the study, we must say that several variables were omitted, in particular those relating to the basic training of respondents as well as information on other stakeholders, namely: beneficiaries, external consultants, the state and donors.

Given the scarcity of studies aimed at optimizing the effect of the practice of monitoring and evaluation in Mali so that it ceases to be a fashion effect and becomes truly involved in the development process through relevant, effective support and efficient in project management, we can only qualify this study as exploratory.

In view of the results obtained in this research work, the organizations involved in the implementation of development projects in Mali must ensure the skills of the personnel involved in the management system in general and in monitoring and evaluation in particular. Once this prerequisite has been established and in order to meet the needs of the project, these skills must be reinforced through appropriate training, involving both the project manager and the team responsible for monitoring and evaluation. These trainings should be oriented especially towards understanding the usefulness of monitoring and evaluation, the implementation mechanisms and the use of the results in decision-making.

At the level of mid-term, final and ex post evaluations, it will increasingly be necessary to involve external consultants who can provide a neutral point of view likely to improve the results obtained at the end of the implementation operation of monitoring and evaluation.

To optimize the overall results of the project in the short, medium and long term by carrying out effective monitoring and evaluation, the project designers can also provide support for the development of managers' skills.

\section{Bibliographical references}

1. Afitep., Management de projets principes et pratique. AFNOR. 1998. 278 pages.

2. Bridier., Michaïlof., Guide pratique d'analyse de projets. Economica.1987.

3. Casley D.J., Kumar K., Suivi et évaluation des projets agricoles. Economica. Banque mondiale. 1987. 165 pages.

4. De Amorin A., Cavalier B., Fabre-Baudry M.F., Guide de l'évaluation. DGCID. Paris. 2004. 63 pages.

5. Descroix S., Leloup C., Organiser l'évaluation d'une action de développement dans le sud : un guide pour les ONG du nord. COTA. Bruxelles. 2002. 82 pages.

6. Djuatio E., Management des projets : Techniques d'évaluation, analyse, choix et planification. Editions INNOVAL. Collection l'esprit économique. L'Harmatan. Série cours principaux. 2004.

7. Groupe Urd., Etude global sur les mécanismes de consultation et de participation des bénéficiaires et des populations affectées dans la programmation, la gestion, le suivi et l'évaluation de l'action humanitaire. 2002. www.globalstudyparticipation.org consulte en Octobre 2016

8. Gueneau MC., Beaudoux E., L'évaluation, un outil au service de l'action. IRAM. F3E. Paris 1996.

9. Horton D., et Coll., L'évaluation au cœur du renforcement organisationnel : Expériences d'organisations de recherche et développement du monde entier. ISNAR / CRDI/ CTA. 2004. 204 pages.

10. Http//: www.cota.be/SPIP/IMG/pdf/Fiche_1A_GCP_SWOT.pdf . Consulté en Octobre 2016

11. Ifad., Guide pratique de suivi évaluation des projets de développement rural : pour une gestion orientée vers l'impact. 2003. www.ifad.org/evaluation/guide f/index.htm - 29k consulté en octobre 2016

12. Imfeld J., Kalt P., Manuel de l'auto-évaluation : cahier thématique d'auto évaluation, cahier de suggestion méthodologique pour l'auto-évaluation. DDC. Berne. Suisse. 46 pages.

13. Le Bissonais J., Management de projet de A à Z. collection ouvrage. AFNOR. Juillet 2003. 320 pages.

14. Maders H.P., Clet E., Pratiquer la conduite de projet. Editions de l'organisation.2005. 243 pages.

15. Marisol E., et Coll., L'évaluation et le suivi participatif : Apprendre du changement. Karthala / CRDI. 2004. 204 pages.

16. Neu D., Des outils pour programmer, suivre, évaluer et présenter ses projets : faciliter la mise en débat et se 
référer aux objectifs initiaux à chaque étape d'un projet. http://www.gret.org/ressource/pdf consulté en Octobre 2016

17. Neu D., Evaluer : apprécié la qualité pour faciliter la décision. Six notes pour contribuer à l'efficacité des évaluations.2001. http://www.gret.org/ressource/pdf consulté en Octobre 2016

18. Pnud et Fem., Dossier d'information sur le suivi évaluation. http://.undp.org/sgp/index.htmconsulté en Octobre 2016 Banque mondiale. Séminaire de formation en suivi en suivi évaluation. Niger. 2002.http://www.pnud.ne/rense/auto\%20formation.htm consulté en novembre 2016

19. Tenenhaus M., Statistiques, Méthodes pour décrire, expliquer et prévoir. Dunod. Paris 2007. 679 pages

20. Vallet G., Techniques de suivi de projets. Collection L'usine nouvelle. Dunod. Paris 2003. 197 pages.

21. Verrière V. Le suivi d'un projet de développement : démarche, dispositif, indicateurs. Paris. 2002. http://f3e.asso.fr consulté en Octobre 2016. 